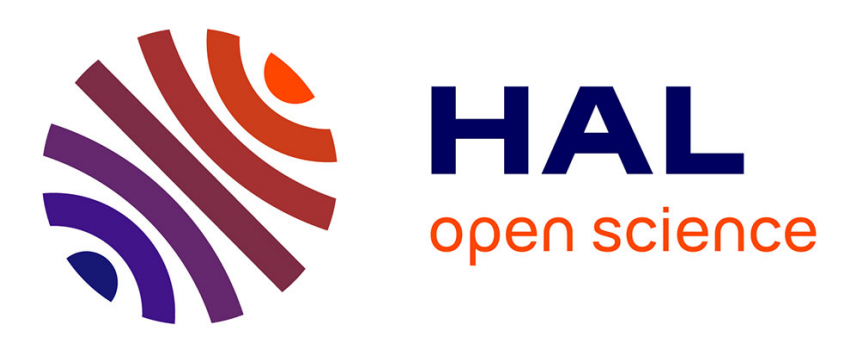

\title{
Effect of capacitation on the endocannabinoid system of mouse sperm
}

Giuseppina Catanzaro, Natalia Battista, Gianna Rossi, Monia Di Tommaso, Mariangela Pucci, Valentina Pirazzi, Sandra Cecconi, Mauro Maccarrone

\section{- To cite this version:}

Giuseppina Catanzaro, Natalia Battista, Gianna Rossi, Monia Di Tommaso, Mariangela Pucci, et al. Effect of capacitation on the endocannabinoid system of mouse sperm. Molecular and Cellular Endocrinology, 2011, 343 (1-2), pp.88. 10.1016/j.mce.2011.01.022 . hal-00723606

\section{HAL Id: hal-00723606 https://hal.science/hal-00723606}

Submitted on 11 Aug 2012

HAL is a multi-disciplinary open access archive for the deposit and dissemination of scientific research documents, whether they are published or not. The documents may come from teaching and research institutions in France or abroad, or from public or private research centers.
L'archive ouverte pluridisciplinaire HAL, est destinée au dépôt et à la diffusion de documents scientifiques de niveau recherche, publiés ou non, émanant des établissements d'enseignement et de recherche français ou étrangers, des laboratoires publics ou privés. 


\section{Accepted Manuscript}

Title: Effect of capacitation on the endocannabinoid system of mouse sperm

Authors: Giuseppina Catanzaro, Natalia Battista, Gianna Rossi, Monia Di Tommaso, Mariangela Pucci, Valentina Pirazzi, Sandra Cecconi, Mauro Maccarrone

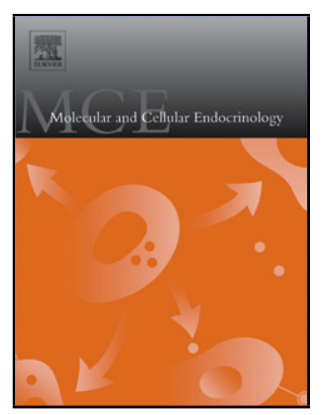

PII:

DOI:

Reference:

S0303-7207(11)00081-5

To appear in: $\quad$ Molecular and Cellular Endocrinology

Received date: $\quad 13-12-2010$

Revised date: 28-1-2011

Accepted date: $\quad$ 28-1-2011

Please cite this article as: Catanzaro, G., Battista, N., Rossi, G., Di Tommaso, M., Pucci, M., Pirazzi, V., Cecconi, S., Maccarrone, M., Effect of capacitation on the endocannabinoid system of mouse sperm, Molecular and Cellular Endocrinology (2010), doi:10.1016/j.mce.2011.01.022

This is a PDF file of an unedited manuscript that has been accepted for publication. As a service to our customers we are providing this early version of the manuscript. The manuscript will undergo copyediting, typesetting, and review of the resulting proof before it is published in its final form. Please note that during the production process errors may be discovered which could affect the content, and all legal disclaimers that apply to the journal pertain. 


\section{Effect of capacitation on the endocannabinoid system of mouse sperm}

Giuseppina Catanzaro ${ }^{1,2 \#}$, Natalia Battista ${ }^{1 \#}$, Gianna Rossi ${ }^{3}$, Monia Di Tommaso ${ }^{1}$, Mariangela Pucci $^{1}$, Valentina Pirazzi ${ }^{1}$, Sandra Cecconi $^{3}$ and Mauro Maccarrone ${ }^{1,2^{*}}$

${ }^{1}$ Department of Biomedical Sciences, University of Teramo, Teramo 64100, Italy. ${ }^{2}$ European Center for Brain Research (CERC)/Santa Lucia Foundation I.R.C.C.S., Rome 00143, Italy.

${ }^{3}$ Department of Health Sciences, University of L'Aquila, L'Aquila 67100, Italy.

${ }^{\#}$ Equally first authors.

\section{*Corresponding author:}

Prof. Mauro Maccarrone, Department of Biomedical Sciences, University of Teramo

Piazza A. Moro 45, I-64100 Teramo, Italy.

Tel: +390861 266875; Fax: +390861266877

E-mail: mmaccarrone@unite.it

Keywords: Anandamide, 2-Arachidonoylglycerol, Capacitation, Mouse sperm. 


\begin{abstract}
The presence of the elements of the endocannabinoid system (ECS) in sperm isolated from several species (from invertebrates to mammals, humans included) has supported the "evolutionary theory" that proposes endocannabinoids as check points in reproductive events like capacitation. In this study, we characterized the ECS elements at the mRNA, protein and functional levels in mouse sperm before and after capacitation. We found that the latter process increases the endogenous levels of the two major endocannabinoids (anandamide and 2-arachidonoylglycerol), through a decreased degradation and increased biosynthesis, respectively. Additionally, we found that the binding activity of cannabinoid receptors was not affected by sperm capacitation, whereas that of vanilloid receptor was reduced. Overall, our data demonstrate that mouse sperm have a fully functional ECS, and that capacitation alters the endogenous tone of the major endocannabinoids through distinct mechanisms.
\end{abstract}




\section{INTRODUCTION}

Endocannabinoids (eCBs) are lipid compounds able to bind to both type $1\left(\mathrm{CB}_{1}\right)$ and type $2\left(\mathrm{CB}_{2}\right)$ cannabinoid receptors (Howlett et al., 2002). In the last few years a great deal of data have been accumulated, suggesting that eCBs have important actions in the reproductive system. In fact, all the essential components of the ECS have been demonstrated in sperm from various mammals (reviewed by Battista et al., 2008; Pierantoni et al., 2009). The presence of $\mathrm{CB}_{1}$, but not $\mathrm{CB}_{2}$, in both testicular and isolated sperm from all analyzed vertebrates suggests an evolutionarily conserved role of $\mathrm{CB}_{1}$-dependent eCBs signalling in sperm physiology (Pierantoni et al., 2009). In fact AEA, the best characterized eCB together with 2-arachidonoylglycerol (2-AG), is implicated in the inhibition of sperm motility and acrosome reaction via $\mathrm{CB}_{1}$ activation (Maccarrone et al., 2005; Rossato et al., 2005; Cobellis et al., 2006), and inhibits sperm capacitation, a complex series of structural and functional changes which include reorganization of sperm membrane phospholipids and proteins (Gadella et al., 2008), reduction in membrane cholesterol levels (Yanagimachi, 1994), and changes in sperm motility, known as hyperactivation (Yanagimachi, 1994). Moreover, AEA has also been detected in female reproductive fluids (Schuel et al., 2002), where capacitation normally occurs, further supporting the idea that eCBs are check-points in reproduction. More recently, a key role for 2-AG has been proposed in the modulation of mouse spermatogenesis (Grimaldi et al., 2009). However, the molecular details of ECS elements and eCBs signalling in controlling sperm function and male fertility remain elusive (Maccarrone, 2009; Taylor et al., 2010). The aim of this study was to ascertain the presence and functionality of the main ECS elements in mouse sperm, and the possible effect of capacitation on their activity and expression. To this end, we measured in mouse sperm mRNA, protein and activity of the AEA synthetase NAPE-PLD ( $N$ acylphosphatidylethanolamine-specific phospholipase D) and hydrolase FAAH (fatty acid amide hydrolase), of the 2-AG synthetase DAGL (diacylglycerol lipase) and hydrolase MAGL (monoacylglycerol lipase), and of their $\mathrm{CB}_{1}$ and $\mathrm{CB}_{2}$ target receptors (Bari et al., 2010). In addition, we ascertained the presence of the AEA-binding TRPV1 (transient receptor potential vanilloid 1) channels, that control the acrosome reaction (Maccarrone et al., 2005) and modulate sperm-oocyte interactions in humans (Francavilla et al., 2009). 


\section{MATERIALS and METHODS}

Chemicals were of the purest analytical grade. Anandamide ( $N$-arachidonoylethanolamine, AEA) and 5-(1,10-dimethylheptyl)-2-[(1R,5R)-hydroxy-(2R)-(3-hydroxypropyl)-cyclohexyl] phenol (CP55940) were purchased from Sigma Chemical Co. (St. Louis, MO, USA). 2Arachidonoylglycerol (2-AG) and resinferatoxin (RTX) were from Alexis (San Diego, CA, USA). AEA-ethanolamine-1- $\left[{ }^{3} \mathrm{H}\right] \quad(60 \mathrm{Ci} / \mathrm{mmol}), \quad\left[{ }^{3} \mathrm{H}\right] \mathrm{CP} 55.940 \quad(126 \mathrm{Ci} / \mathrm{mmol})$ and $\left[{ }^{3} \mathrm{H}\right] \mathrm{RTX} \quad(43$ $\mathrm{Ci} / \mathrm{mmol}$ ) were purchased from Perkin Elmer Life Sciences (Boston, MA, USA). $N$ $\left[{ }^{3} \mathrm{H}\right]$ Arachidonoyl-phosphatidylethanolamine $\left(\left[{ }^{3} \mathrm{H}\right]\right.$ NArPE, $\left.200 \mathrm{Ci} / \mathrm{mmol}\right)$ was from ARC (St. Louis, MO, USA). $\quad\left[{ }^{14} \mathrm{C}\right] 1$-Stearoyl-2-arachidonoyl-sn-glycerol $(56 \mathrm{mCi} / \mathrm{mmol})$ was from Amersham Biosciences. $\mathrm{d}_{8}$-AEA, $\mathrm{d}_{8}-2-\mathrm{AG}$, rabbit anti-NAPE-PLD and anti-MAGL polyclonal antibodies were from Cayman Chemicals (Ann Arbor, MI, USA). Rabbit anti-CB ${ }_{1}$ and anti-CB polyclonal antibodies were from ABR-Affinity BioReagents (Golden, CO, USA); rabbit antiTRPV1 and anti-FAAH polyclonal antibodies were from Santa Cruz Biotechnologies (Santa Cruz, CA, USA); rabbit anti-DAGL polyclonal antibodies were from Frontier Science Co. 1td (Okkaido, Japan)Goat Alexa Fluor conjugates secondary antibodies and Prolong antifade kit were from Molecular Probes (Eugene, OR, USA).

\section{Animals}

Adult (90- to 120-day-old) swiss CD1 male mice of proven fertility, and 2-month-old swiss CD1 female mice were purchased from Charles River Italia (Como, Italy). All efforts were made to minimize animal suffering and to reduce the number of mice used, in accordance with the European Communities Council Directive of 24 November, 1986 (86/609/EEC). The local committees on animal care and use approved all experimental protocols, that were applied according to accepted veterinary medical practice.

\section{Sperm preparation}

Spermatozoa were released from the cauda epididymis by mincing the large diameter tubules in 1 $\mathrm{ml}$ of warmed equilibrated HTF medium, supplemented with $0.4 \%$ BSA to obtained capacitated sperm, or as such for resting sperm, respectively. After removing tissue fragments, sperm were capacitated for $2 \mathrm{~h}$ at $37^{\circ} \mathrm{C}$. Both capacitated and resting spermatozoa were washed, counted and frozen.

\section{In vitro fertilization}

In vitro fertilization (IVF) was performed on ovulated eggs ( $\mathrm{n}=150$ /group), which were devoid of zona pellucida. Eggs were inseminated for $1 \mathrm{~h}$ and analyzed for the presence of male and female pronuclei $6 \mathrm{~h}$ later, as previously described $(\mathrm{n}=150)($ Cecconi et al., 1996). 


\section{Cholesterol quantitation}

Sperm were homogenized and membrane lipids were extracted, evaporated under $\mathrm{N}_{2}$ stream and fractionated on silica polypropylene plates by thin layer chromatography, as reported (Maccarrone et al., 2009). Then, plates were dried and placed on a Heidolph plate heater, cholesterol bands were scanned using an Image Scanner (Amersham Biosciences, Fairfield, CT, USA), and the values obtained were quantitated by means of standard curves obtained with cholesterol standards.

\section{qRT-PCR analysis}

RNA was extracted from sperm using the RNeasy extraction kit (Qiagen, Crawley, UK), as suggested by the manufacturer. Quantitative real time reverse transcriptase-polymerase chain reaction (qRT-PCR) assays were performed as previously described (Grimaldi et al., 2009).

\section{Endogenous levels of AEA and 2-AG}

Sperm were subjected to lipid extraction with chloroform/methanol (2:1, v/v). Endocannabinoid content was determined by liquid chromatography-electrospray ionization mass spectrometry (LCESI-MS), as described (Francavilla et al., 2009).

\section{Receptor binding assays}

Cannabinoid and vanilloid receptor studies were performed by rapid filtration assays, as previously reported (Francavilla et al., 2009).

\section{Enzymatic activities}

The metabolism of AEA through NAPE-PLD and FAAH, and that of 2-AG through DAGL and MAGL were assayed as detailed elsewhere (Catani et al., 2009).

\section{Immunocytochemical analysis}

Immunocytochemistry was performed as detailed elsewhere (Catanzaro et al., 2009), using the following antibody dilutions: anti-CB 1 (1:400), anti-CB 2 (1:400), anti-TRPV1 (1:100), anti-NAPEPLD (1:400), anti-FAAH (1:200), anti-DAGL (1:200) or anti-MAGL (1:400). Pictures were taken using the LAS AF program (Leica Microsystems). Quantification was performed using 5 images for each condition, and measuring fluorescence intensity of each sperm cell in the field (10 cells were analyzed for each image). Non-specific fluorescence was always subtracted from the total fluorescence (see Supplementary Material for negative controls). Also bright-field images were taken from resting and capacitated sperm, in order to check the anatomical features of these cells (Supplementary Material). 


\section{Statistical analysis}

Statistical analysis was performed through paired Student's $t$ test for IVF data, and unpaired Student's $t$ test for the other experiments (GraphPAD Software for Science, San Diego, CA, USA). All data were reported as mean \pm S.E.M. of at least three independent experiments, each performed in duplicate.

\section{RESULTS}

\section{In vitro fertilization and capacitation of mouse sperm}

Metaphase II-arrested oocytes were incubated with resting and capacitated mouse sperm and their ability to form a male pronucleus was tested. As reported in Table 1,70\% of oocytes showed the presence of female and male pronuclei following IVF with capacitated mouse sperm, compared to $3 \%$ of those fertilized with resting sperm. In addition, reduction in membrane cholesterol content (down to $45 \%$ ), an hallmark of capacitation (Go and Wolf, 1985; Belmonte et al., 2005; Gadella et al., 2008), was documented in capacitated versus resting sperm (Table 2), further corroborating that the capacitation process was fully effective.

\section{Presence of active ECS elements in mouse sperm}

Resting and capacitated mouse sperm express all major ECS components both at mRNA (Fig. 1) and protein (Fig. 2) levels. All ECS elements were functional, as demonstrated through activity and binding assays (Table 3). In particular, NAPE-PLD activity was not affected by the capacitation process, whereas FAAH activity significantly decreased by $\sim 25 \%$ (Table 3 ). Conversely, capacitation dramatically increased DAGL activity ( $\sim$-fold over resting cells), while slightly reducing MAGL activity (Table 3 ). In keeping with these activity data, both endogenous levels of AEA and 2-AG increased in capacitated versus resting sperm, up to $~ 9$-fold and $~ 4$-fold respectively (Table 2). Incidentally, in the case of AEA these data corroborate previous findings in boar sperm (Maccarrone et al., 2005). In addition, the binding activity of CB receptors was not affected by capacitation, whereas that of TRPV1 was reduced by $\sim 20 \%$ (Table 3 ). These functional data were paralleled by alterations of gene expression at the transcriptional and translational levels, that were consistent with the activity data for MAGL (with a non-significant trend for FAAH, DAGL and TRPV1) at the mRNA level (Fig. 1), and for DAGL, CBR and TRPV1 (with a nonsignificant trend for MAGL) at the protein level (Fig. 2). The data on protein expression of DAGL and TRPV1 were further corroborated by Western blotting and enzyme-linked immunosorbent assay (ELISA), shown in the Supplementary Material. It can be noted that mRNA and protein expression of some of the ECS elements (e.g., $\mathrm{CB}_{1} \mathrm{R}$ and FAAH) were differently affected by capacitation. In this context, there are several reports showing significant differences between transcript and protein levels of ECS components under different experimental paradigms (Fonseca 
et al., 2009; Bari et al., 2011). These reports and our data suggest that the expression of ECS genes can be regulated in a different manner at the transcription and translation levels.

\section{Localization of ECS elements in mouse sperm}

The localization of ECS components in resting and capacitated mouse sperm was determined also by means of confocal microscopy. $\mathrm{CB}_{1}$ was found to be restricted in the anterior and post-acrosomal region of sperm head, whereas $\mathrm{CB}_{2}$ was localized at the sperm head in the post-acrosomal region and, less intensely, in the sperm tail; only in a few cells, $\mathrm{CB}_{2}$ staining was observed in the front part of the head (Fig. 2). The other ECS elements were clearly detectable on the sperm head, where they seemed to be confined in the post-acrosomal region (Fig. 2). Moreover, NAPE-PLD was detected on the sperm tail, and FAAH was detected on the whole sperm cell. The subcellular localization of all ECS members did not change in capacitated versus resting sperm (Fig. 2).

\section{DISCUSSION}

In this study we demonstrate that mouse sperm, much alike boar (Maccarrone et al., 2005) and human sperm (Francavilla et al., 2009), express the major components of ECS needed to synthesize and degrade the two most prominent eCBs, AEA and 2-AG. We also show that mouse sperm express functional eCBs-binding $\mathrm{CB}_{1}, \mathrm{CB}_{2}$ and TRPV1 receptors. It should be noted that in mouse sperm protein expression of $\mathrm{CB}_{2}$ was almost the same as that of $\mathrm{CB}_{1}$ (Fig. 2), at variance with its faint expression reported in boar (Maccarrone et al., 2005) and human sperm (Francavilla et al., 2009). In line with this, a recent study has shown $\mathrm{CB}_{2}$ in the developing mouse sperm, disclosing a pivotal role for this $\mathrm{CB}$ receptor subtype in spermatogenesis (Grimaldi et al., 2009). However, neither $\mathrm{CB}_{1}$ nor $\mathrm{CB}_{2}$ were affected by the capacitation process, whereas TRPV1, that binds AEA but not 2-AG, was clearly down-regulated. These data suggest that TRPV1-mediated activities of AEA can be critical also for mouse sperm, and the increase of the intracellular levels of AEA in capacitated sperm (Table 2), due to reduced FAAH activity (Table 3), further supports this hypothesis. On the other hand, only recently a few studies have focused on the role of 2-AG in male fertility, disclosing its impact on mouse spermatogenesis (Grimaldi et al., 2009) and epididymal start-up (Cobellis et al., 2010). Interestingly, in those studies the metabolic control of 2-AG content was shown to be due to enhanced transcriptional and translational levels of DAGL, and decreased expression of MAGL (Grimaldi et al., 2009). Here, we show that capacitation appears to recapitulate this type of regulation, because it increases 2-AG content by enhancing the activity and expression of DAGL, while reducing that of MAGL. In this context, it seems noteworthy that the capacitation process leads to a hyperactive tone of both AEA and 2-AG, although through distinct mechanisms: reduced degradation by FAAH (in the case of AEA), or enhanced synthesis by DAGL (in the case of 2-AG). It can be suggested that these distinct pathways might allow a differential regulation of the content, and hence of the biological activity, of the two major eCBs, an 
unprecedented observation that might extend well-beyond reproductive events. It should be recalled that in previous studies we have shown that intracellular levels of AEA increase during capacitation and contribute to promote the fertilizing ability of both boar (Maccarrone et al., 2005) and human sperm (Francavilla et al., 2009), by activating TRPV1 receptors at an intracellular binding site. In addition, AEA present in both seminal plasma and uterine fluids prevents premature capacitation in freshly ejaculated sperm via a $\mathrm{CB}_{1} \mathrm{R}$-mediated mechanism (Battista et al., 2008). Overall, it can be speculated that an increase of intracellular AEA can activate TRPV1 receptors and, by means of an export mechanism through a membrane transporter, it can contribute to maintain a suitable extracellular concentration for the activation of $\mathrm{CB}_{1} \mathrm{R}$, thus facilitating the sperm journey along the uterine tract. $A$ further activation of $\mathrm{CB}_{1} \mathrm{R}$ can be warranted also by intracellular 2-AG, once exported outside the cell. Therefore the two eCBs, by acting either extracellularly at $\mathrm{CB}_{1} \mathrm{R}$ or intracellularly at TRPV1, may play a key-role in controlling capacitation, as well as the spatiotemporal interaction of sperm with egg and the sperm-oocyte fusion process.

In conclusion, we show that mouse sperm have a fully functional endocannabinoid system, able to metabolize and bind the two major eCBs: AEA and 2-AG. We also show that capacitation remarkably enhances the endogenous tone of both eCBs through distinct mechanisms, a finding that might open new opportunities for therapeutic intervention. The present data might also help to develop transgenic mice, where different ECS elements can be knocked down or knocked in, and then can be exploited to further understand dysfunctions in male fertility.

\section{Acknowledgments}

The authors wish to thank Dr. Nicola Ferri (Istituto Zooprofilattico Sperimentale, Teramo) for his kind support on animal care and housing, and Fondazione TERCAS (2009-2012 contract) for financial support to MM.

\section{References}

Bari, M., Battista, N., Pirazzi, V., Maccarrone, M., 2010. The mainfold actions of endocannabinoids on female and male reproductive events. Front. Biosci. 16, 498-516.

Bari, M., Tedesco, M., Battista, N., Pasquariello, N., Pucci, M., Gasperi, V., Scaldaferri, M.L., Farini, D., De Felici, M., Maccarrone, M., 2011. Characterization of the endocannabinoid system in mouse embryonic stem cells. Stem Cells Dev. 20, 139-147.

Battista, N., Rapino, C., Di Tommaso, M., Bari, M., Pasquariello, N., Maccarrone, M., 2008. Regulation of male fertility by the endocannabinoid system. Mol. Cell. Endocrinol. 286, S17-23.

Belmonte, S.A., López, C.I., Roggero, C.M., De Blas, G.A., Tomes, C.N., Mayorga, L.S., 2005. Cholesterol content regulates acrosomal exocytosis by enhancing Rab3A plasma membrane association. Dev. Biol. 285, 393-408. 
Catani, M.V., Fezza, F., Baldassarri, S., Gasperi, V., Bertoni, A., Pasquariello, N., Finazzi-Agrò, A., Sinigaglia, F., Avigliano, L., Maccarrone, M., 2009. Expression of the endocannabinoid system in the bi-potential HEL cell line: commitment to the megakaryoblastic lineage by 2arachidonoylglycerol. J. Mol. Med. 87, 65-74.

Catanzaro, G., Pasquariello, N., Marzano, V., Amadio, D., Barcaroli, D., Oddi, S., Federici, G., Urbani, A., Finazzi-Agrò, A., Maccarrone, M., 2009. Characterization of the endocannabinoid system in human neuronal cells and protomi analysis of anandamide induced apoptosis. J. Biol. Chem. 284, 29413-29426.

Cecconi, S., D’Aurizio, R., Colonna, R., 1996. Role of antral follicle development and cumulus cells on in vitro fertilization of mouse oocytes. J. Reprod. Fertil. 107, 207-214.

Cobellis, G., Cacciola, G., Scarpa, D., Meccariello, R., Chianese, R., Franzoni, M.F., Mackie, K., Pierantoni, R., Fasano, S., 2006. Endocannabinoid system in frog and rodent testis: type-1 cannabinoid receptor and fatty acid amide hydrolase activity in male germ cells. Biol. Reprod. 75, 82-89.

Cobellis, G., Ricci, G., Cacciola, G., Orlando, P., Petrosino, S., Cascio M.G., Bisogno, T., De Petrocellis, L., Chioccarelli, T., Altucci, L., Fasano, S., Meccariello, R., Pierantoni, R., Ledent, C., Di Marzo, V., 2010. A gradient of 2-arachidonoylglycerol regulates mouse epididymal sperm cell start-up. Biol. Reprod. 82, 451-458.

Fonseca, B.M., Correia-da-Silva, G., Taylor, A.H., Konje, J.C., Bell, S.C., Teixeira, N.A., 2009. Spatio-temporal expression patterns of anandamide-binding receptors in rat implantation sites: evidence for a role of the endocannabinoid system during the period of placental development. Reprod. Biol. Endocrinol. 7, 121.

Francavilla, F., Battista, N., Barbonetti, A., Vassallo, M.R.C., Rapino, C., Antonangelo, C., Pasquariello, N., Catanzaro, G., Barboni, B., Maccarrone, M., 2009. Characterization of the endocannabinoid system in human spermatozoa and involvement of TRPV1 vanilloid receptor in their fertilizing ability. Endocrinology 150, 4692-4700.

Gadella, B.M., Tsai, P.S., Boerke, A., Brewis, I.A., 2008. Sperm head membrane reorganisation during capacitation. Int. J. Dev. Biol. 52, 473-480.

Go, K.J., Wolf, D.P., 1985. Albumin-mediated changes in sperm sterol content during capacitation. Biol. Reprod. 32, 145-153. 
Grimaldi, P., Orlando, P., Di Siena, S., Lolicato, F., Petrosino, S., Bisogno, T., Geremia, R., De Petrocellis, L., Di Marzo, V., 2009. The endocannabinoid system and pivotal role of the CB2 receptor in mouse spermatogenesis. Proc. Natl. Acad. Sci. USA 106, 11131-11136.

Howlett, A.C., Barth, F., Bonner, T.I., Cabral, G., Casellas, P., Devane, W.A., Felder, C.C., Herkenham, M., Mackie, K., Martin, B.R., Mechoulam, R., Pertwee, R.G., 2002. International Union of Pharmacology. XXVII. Classification of cannabinoid receptors. Pharmacol. Rev. 54, 161 202.

Maccarrone, M., 2009. Endocannabinoids: friends and foes of reproduction. Prog. Lipid Res. 48, 344-354.

Maccarrone, M., Barboni, B., Paradisi, A., Bernabò, N., Gasperi, V., Pistilli, M.G., Fezza, F., Lucidi, P., Mattioli, M., 2005. Characterization of the endocannabinoid system in boar spermatozoa and implications for sperm capacitation and acrosome reaction. J. Cell. Sci. 118, 4393-4404.

Maccarrone, M., De Chiara, V., Gasperi, V., Viscomi, M.T., Rossi, S., Oddi, S., Molinari, M., Musella, A., Finazzi Agrò, A., Centonze, D., 2009. Lipid rafts regulate 2-arachidonoylglycerol metabolism and physiological activity in the striatum. J. Neurochem. 109, 371-381.

Pierantoni, R., Cobellis, G., Meccariello, R., Cacciola, G., Chianese, R., Chioccarelli, T., Fasano, S., 2009. CB1 activity in male reproduction: Mammalian and nonmammalian animal models. Vitam. Horm. 81, 368-387.

Rossato, M., Ion Popa, F., Ferigo, M., Clari, G., Foresta C., 2005. Human sperm express cannabinoid receptor $\mathrm{Cb} 1$, the activation of which inhibits motility, acrosome reaction, and mitochondrial function. J. Clin. Endocrinol. Metab. 90, 984-991.

Schuel, H., Burkman, L.J., Lippes, J., Crickard, K., Forester, E., Piomelli, D., Giuffrida, A., 2002. N-Acylethanolamines in human reproductive fluids. Chem. Phys. Lipids 121, 211-227.

Taylor, A.H., Amoako, A.A., Bambang, K., Karasu, T., Gebeh, A., Lam, P.M., Marzcylo, T.H., Konje, J.C., 2010. Endocannabinoids and pregnancy. Clin. Chim. Acta, 411, 921-930.

Yanagimachi, R., 1994. Mammalian fertilization. In: Knobil, E., Neill, J.D. (Eds.), Physiology of Reproduction, second ed. Raven Press, Ltd., New York, pp. 189-317. 


\section{Figure Legends}

Figure 1. qRT-PCR analysis of ECS elements in mouse sperm. Representative quantitative reverse transcriptase-polymerase chain reaction (qRT-PCR) analysis of mRNA expression of ECS members in resting and capacitated mouse sperm. The mRNA level of each element of the ECS was expressed as fold over NAPE-PLD mRNA, set to 1.0 for resting sperm. *Denotes $\mathrm{p}<0.05$ versus resting sperm.

Figure 2. Immunocytochemical analysis of ECS in mouse sperm. The presence and localization of endocannabinoid-binding $\mathrm{CB}_{1}, \mathrm{CB}_{2}$ and TRPV1 receptors, of AEA metabolic enzymes (NAPEPLD and FAAH), and of 2-AG metabolic enzymes (DAGL and MAGL) were ascertained in resting and capacitated sperm by means of confocal laser-scanning microscopy. Non-specific immunofluorescence in these cells was negligible for all tested antibodies (Supplementary material). The $\mathrm{y}$-axis values represent the mean fluorescence per sperm. *Denotes $\mathrm{p}<0.05$ and $* *$ $\mathrm{p}<0.01$ versus resting sperm. Images were taken using a confocal microscope equipped with a $63 \mathrm{X}$ objective (numerical aperture $=1.4$ ), and are representative of at least three independent experiments; five fields were examined for each treatment. Bars, $10 \mu \mathrm{m}$. 
Table 1. Percentage of oocytes showing two pronuclei after IVF with resting or capacitated mouse sperm.

\begin{tabular}{lcc}
\hline Sperm condition & $\begin{array}{c}\text { Total number of } \\
\text { inseminated eggs }\end{array}$ & $\begin{array}{c}\text { Number of eggs with } \\
\text { two pronuclei }\end{array}$ \\
\hline Resting & 150 & $5 \pm 2$ \\
Capacitated & 150 & $105 \pm 6 *$ \\
\hline
\end{tabular}

*Denotes $\mathrm{p}<0.01$ versus eggs inseminated with resting sperm. 
Table 2. Membrane cholesterol content, and endogenous levels of AEA and 2-AG in resting and capacitated mouse sperm.

\begin{tabular}{lcc}
\hline Parameter & Resting & Capacitated \\
\hline Cholesterol content $^{\mathrm{a}}$ & $21.9 \pm 0.9$ & $10.0 \pm 2.5^{*}$ \\
Endogenous levels of AEA & $0.3 \pm 0.1$ & $2.7 \pm 0.3^{* *}$ \\
Endogenous levels of $2-\mathrm{AG}^{\mathrm{b}}$ & $9.6 \pm 1.1$ & $38.3 \pm 9.9^{*}$ \\
\hline
\end{tabular}

${ }^{\mathrm{a}}$ Expressed as $\mu \mathrm{g} / \mathrm{mg}$ of protein.

${ }^{\mathrm{b}}$ Expressed as $\mathrm{fmol} / \mathrm{mg}$ of protein.

$*$ Denotes $\mathrm{p}<0.05$ and $* * \mathrm{p}<0.01$ versus resting sperm. 
Table 3. Activity of ECS elements in resting and capacitated mouse sperm.

\begin{tabular}{lcc}
\hline Parameter & Resting & Capacitated \\
\hline NAPE-PLD activity $^{\mathrm{a}}$ & $13.1 \pm 2.8$ & $9.2 \pm 1.7$ \\
FAAH activity $^{\mathrm{a}}$ & $175 \pm 3$ & $133 \pm 11^{*}$ \\
DAGL activity $^{\mathrm{a}}$ & $57 \pm 6$ & $581 \pm 58^{* *}$ \\
MAGL activity $^{\mathrm{a}}$ & $1596 \pm 4$ & $1496 \pm 8^{*}$ \\
CBRs binding $^{\mathrm{b}}$ & $23.3 \pm 0.9$ & $24.0 \pm 0.6$ \\
TRPV1 binding $^{\mathrm{b}}$ & $64.8 \pm 1.1$ & $53.3 \pm 2.5^{*}$ \\
\hline
\end{tabular}

${ }^{\mathrm{a}}$ Expressed as $\mathrm{pmol} / \mathrm{min}$ per $\mathrm{mg}$ of protein.

${ }^{b}$ Expressed as fmol/mg of protein.

$*$ Denotes $\mathrm{p}<0.05$ and $* * \mathrm{p}<0.01$ versus resting sperm. 


\section{Research Highlights}

1) Characterization of the endocannabinoid system (ECS) in mouse sperm;

2) Effects of capacitation on the expression of ECS elements;

3) Differential upregulation of endocannabinoid tone AEA and 2-AG during capacitation. 


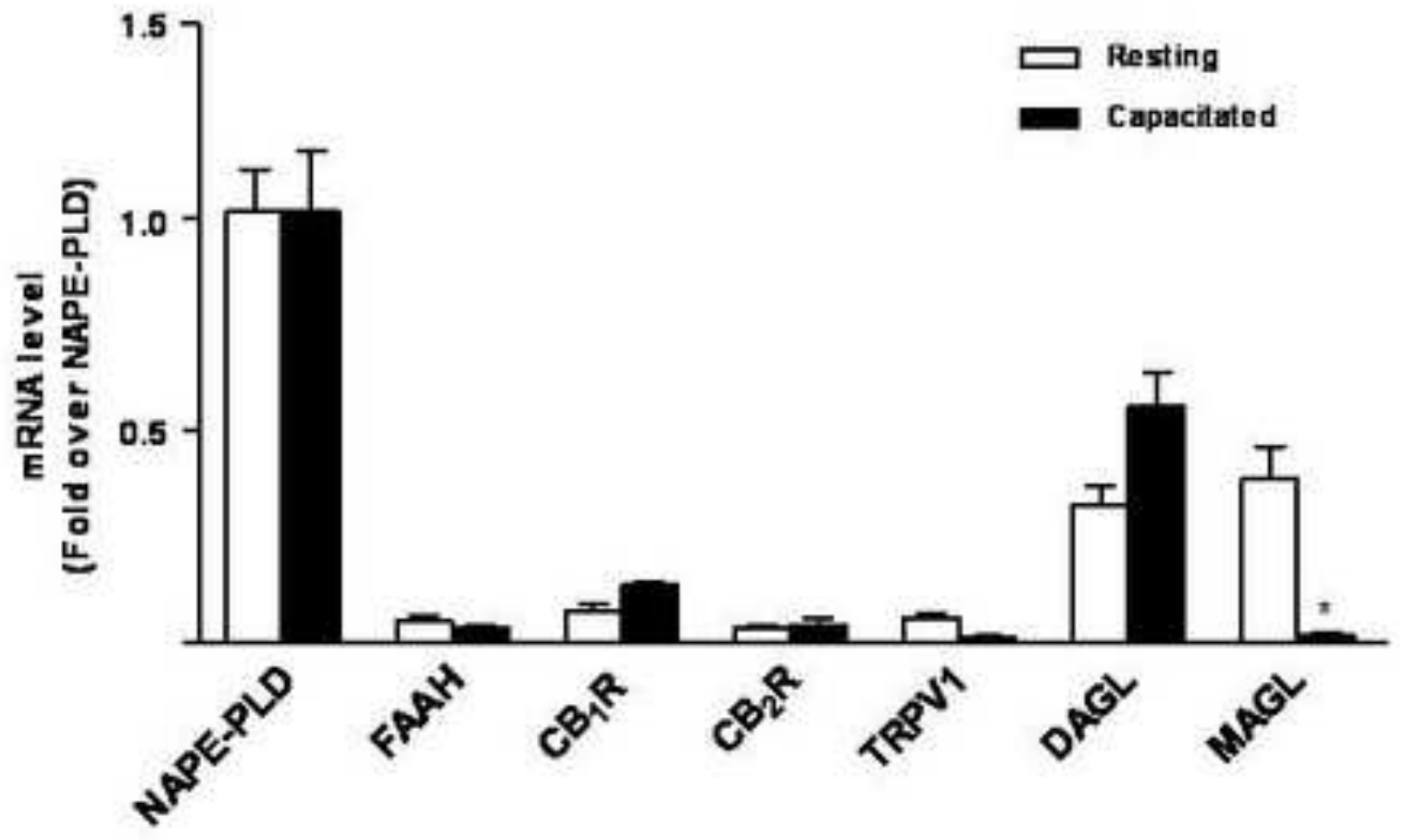




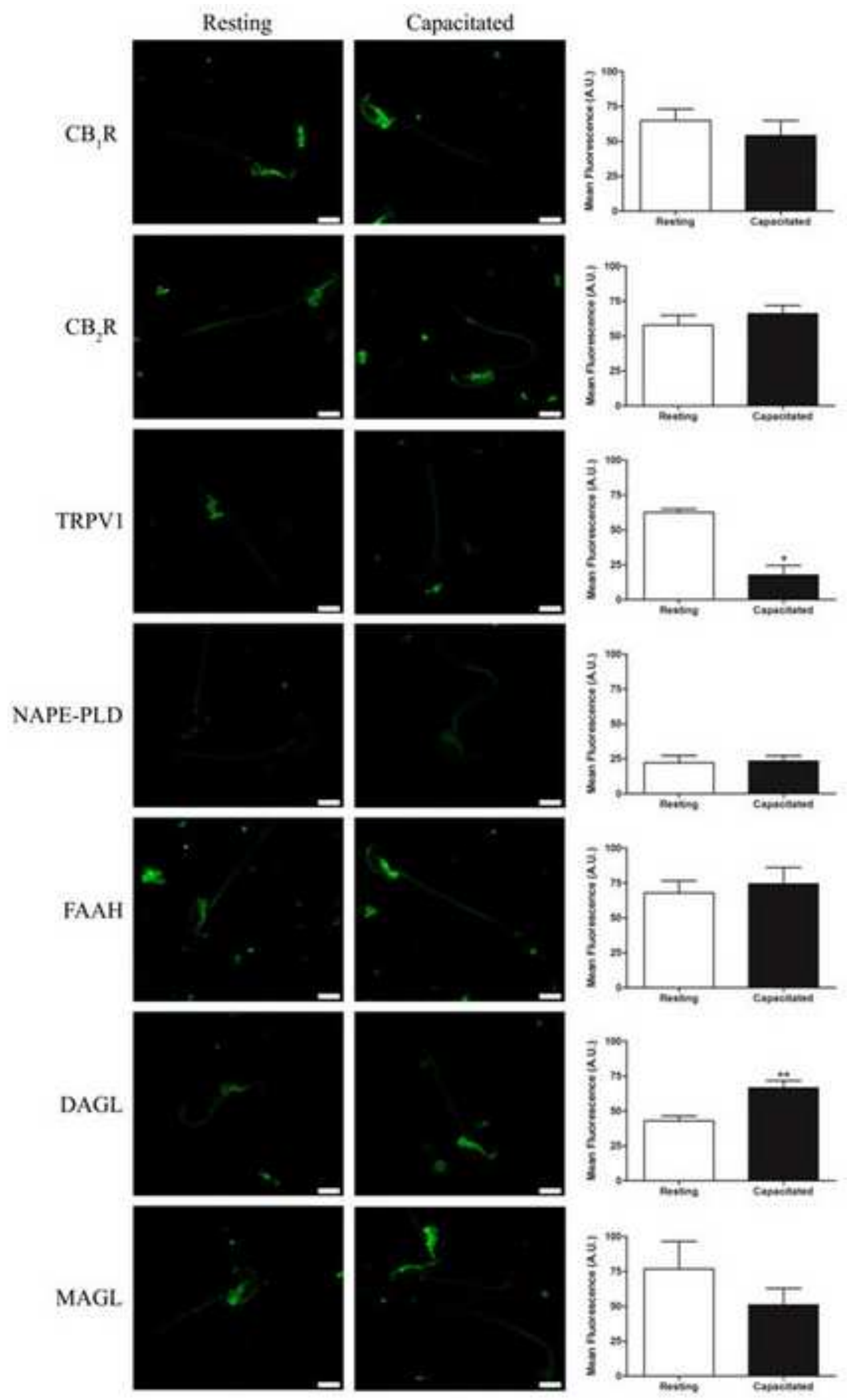

